\title{
Consumption implications of agri-food policies
}

\author{
BY BRUCE TRAILL ${ }^{1,2}$ AND SPENCER HENSON' \\ Departments of ${ }^{1}$ Agricultural Economics and Management and ${ }^{2}$ Food Science and \\ Technology, The University of Reading, PO Box 237, Reading RG6 6AR
}

Economists have spent a considerable amount of time debating what is meant by the term 'agri-food policy' (Organization for Economic Cooperation and Development, 1981; Ritson, 1983; Henson et al. 1995). (Nutritionists seem to have devoted similar time to the definition of 'nutrition policy'.) The debate has been somewhat sterile: should the term food policy be used in a narrow sense, to include only those policies the main aim of which is to influence the agriculture and food sectors in some way (for example, promotion of olive oil consumption or support of agricultural incomes), or be used in a broader sense to include relevant aspects of all policy measures that impinge on the food sector? A narrow view might include the following, in addition to agricultural policy:

(1) labelling and promotion of food products, including the name of products, ingredients, nutritional composition, claims etc.;

(2) food safety and hygiene, including food additives, contamination of food, microbiological hazards, veterinary controls etc.;

(3) food quality, including composition, shape, colour, geographical origin, specific character, method of production etc.

A broader view might also include:

(4) technology policy, which develops innovatory products and processes through research and development;

(5) trade policy, including the General Agreement on Tariffs and Trade (GATT) and the Single European Market;

(6) competition and industrial policy, which affects mergers and acquisitions, restrictive practices etc.

In looking at the nutritional implications of agri-food policy we can afford, in principle, to take a broad view; in practice, few agri-food policies have a significant impact on nutrition, so the discussion focuses on those that do. Primarily, this means the Common Agricultural Policy (CAP), and discussion of CAP effects forms the core of the present paper. The emphasis is on the food consumption implications of the CAP. We will leave nutritionists to deduce the nutritional implications.

Before proceeding to a detailed examination of the impact of CAP, we first provide a brief conceptual approach to the analysis of the economic and non-economic factors that influence food consumption and how major policies (in the broad agri-food policy sense) might be assessed. Following a general discussion of the CAP, the impact of the CAP on consumption of yellow fats is provided as a detailed example.

\section{ANALYSIS OF AGRI-FOOD POLICY IMPACTS}

\section{Economic factors influencing food consumption}

Food consumption patterns change as personal incomes grow. As Engel's Law (Tomek \& Robinson, 1972) states, when incomes rise, the proportion of expenditure allocated to food 
declines. Hence, the income elasticity of demand for food, which measures the percentage increase (or decrease) in consumption of a product resulting from a $1 \%$ increase in income (everything else remaining constant) is lower at higher income levels.

A positive relationship exists between gross national product per capita and the amount of energy derived from livestock products, and a negative relationship with the amount of energy derived from cereals and roots. This reflects the higher income elasticity for meat products (more luxury status) than for staples. As incomes rise, consumers also purchase more convenience products (for example, chilled foods and ready-prepared meals) and eat out more.

In addition to shifts in broad food consumption patterns, as income grows the diversity of food products consumed tends to increase and there are changes in food-related behaviour. For example, the clear relationship between the growth in personal incomes and the demand for convenience foods is related to changes in lifestyle as well as to increases in the economic means with which to satisfy this demand.

Prices remain important determinants of food consumption, although their influence diminishes as incomes rise, so own-price elasticities, which measure the percentage fall in consumption of a product resulting from a $1 \%$ increase in its price (everything else remaining constant), tend to fall as people become better off. Typically, luxury products (for example, certain meats) have price elasticities which are larger in absolute terms than necessities (for example, potatoes). In high-income countries, many food products nowadays have price elasticities close to zero, implying that policies affecting prices have little effect on consumption.

Given that price-policy intervention is often directed at specific products, relative prices are important. The cross-price elasticity relates the percentage change in consumption of one product to a $1 \%$ change in the price of a substitute or complement (everything else remaining constant). Cross-price elasticities for close substitutes (for example, butter and margarine) can be quite large, indicating that actions which affect relative prices can have an important influence on diet. For example, we will argue that the price support afforded to producers of milk in the European Union (EU) has resulted in significant increases in the price of butter $v$. margarine, stimulating a switch from butter to margarine consumption.

\section{Non-economic factors influencing food consumption}

In recent years, the demand for food has been increasingly influenced by a range of noneconomic factors, including demographic and lifestyle changes; and wider socio-economic aspects of food consumption, for example, information concerning diet and health, food safety, the environment and animal welfare.

Demographic and lifestyle changes are widely accepted to have a major impact on food consumption. These include: (1) the increased participation of women in the paid labour force, which has increased demand for convenience products and contributed to the demise of the family meal in favour of 'snacking'; (2) the increase in use of household equipment for the storage and preparation of food, including microwave ovens, freezers and food processors, which have facilitated quicker food preparation and the use of highly-processed convenience foods; (3) a lower level of activity at work and a shorter working week, implying a reduction in requirements for food energy and comparable reductions in the total quantity of food consumed; (4) reductions in the average number of children per household 
and increases in the number of single-person households, influencing the demand for convenience foods and foods mainly consumed by children; (5) an ageing population, since older people eat less and, because they often dine alone, snack more and eat convenience products.

In recent years, food consumption patterns have been influenced by the way in which foods are produced. Many consumers are ambivalent towards, or even reject the use of certain new food technologies and the use of intensive methods of crop and livestock production in agriculture (for example, see Henson, 1995).

Although there is much reference to the mistaken notion that consumers have become more concerned about diet and health in recent years (they always have been, although the nature of those concerns has changed over time), there is little doubt that concerns about the nutritional quality of food products, measured in terms of macro- rather than micronutrients, has a major influence on food markets. This is clearly evidenced by the marketing strategies of the major food manufacturers, now producing a wide range of low-fat and high-fibre products.

Food consumption is also influenced by the availability of particular food products, although new farm and food technologies and growth in the trade in food products have reduced the importance of local conditions in determining food consumption.

Changes in the structure of the food-manufacturing sector have potentially important implications for the availability of foods in particular countries. As the food-manufacturing industry becomes more concentrated (through growth of large firms, disappearance of small- and medium-sized firms, and through mergers and acquisitions), and companies develop European strategies (encouraged by the completion of the Single European Market and the creation of the European Economic Area), there are a growing number of crossEuropean food brands marketed on a European scale. In addition, developments in food technology have facilitated the production of foods preserved in new ways (for example, irradiation) or the formulation of entirely new or fundamentally-modified products (for example, the products of biotechnology).

Another common trend across Europe is the growth in importance of the major multiple food retailers, distributing food through large supermarkets which offer an unprecedented range of products from around Europe and the rest of the world. A major food retail store may have 15000 products on its shelves and introduce 1500 new products each year. Processed food products from all countries have been made available across Europe, tending to diminish the influence of local differences in supply.

While it is generally accepted that non-economic factors have become a major influence on food consumption, the major emphasis of the present paper is the influence of agri-food policy through the mechanism of economic factors. Although agri-food policy can influence food quality, product availability and the degree to which certain products are promoted, it is held that the major influence of the CAP, which is the main topic of the present paper, is through its impact on food prices.

\section{THE IMPACT OF THE COMMON AGRICULTURAL POLICY ON FOOD CONSUMPTION}

The Common Agricultural Policy and health debate

There appears to be a widespread and strongly-held belief amongst nutritionists and the 
'food lobby' that the CAP has discouraged the consumption of a healthy diet. Presumably this has been fuelled by media pictures and reports of 'butter mountains', 'wine lakes' and the destruction of fruit and vegetables. Indeed, the concern amongst nutritionists about the adverse influence of the CAP on diet has found its way into official dietary advice; for example, the 1984 Committee on Medical Aspects of Food Policy report (Department of Health and Social Security, 1984) states that:

'Consideration should be given to ways and means of removing from the Common Agricultural Policy those elements of it which may discourage individuals and families from implementing the recommendations for dietary change'.

The aims of the CAP as established in the Treaty of Rome make no mention of healthy eating. They were:

to increase agricultural productivity by promoting technical progress, and by ensuring the rational development of agricultural production and optimum utilization of factors of production, in particular labour;

to ensure a fair standard of living for the agricultural community, in particular by increasing individual earnings of persons engaged in agriculture;

to stabilize markets;

to assure the availability of supplies;

to ensure supplies reach customers at reasonable prices.

However, the lack of focus on diet does not imply that, as a consequence, the CAP is bad for nutrition and health. Indeed, the following discussion suggests that, to the extent that the impact of the CAP can be isolated from the complex of factors influencing food choices, the CAP may have had what nutritionists may regard as a positive influence on diet.

\section{The mechanisms of the Common Agricultural Policy}

The mechanism through which the CAP has attempted to achieve its main objective (raising farm incomes) has been to raise prices to producers and consumers. Whether or not farmers have really benefited from this in the long run has been the subject of considerable debate among economists. The consensus is that the benefits have been capitalized into land values, so that only those farmers who owned land at the time of entry into the EU have benefited.

In an open economy which exhibits free trade, prices would be established by the interaction of supply and demand in the world market. A 'small' country is defined as one that does not produce or consume enough to influence 'world' prices. Such a country can buy or sell as much as it wishes (or is able) at the prevailing world price. However, the mechanisms employed by the CAP aim to maintain prices paid to farmers above world prices. While the specific mechanisms have varied from product-to-product, they have generally involved:

(1) intervention buying to set a lower limit to domestic prices. If supply is greater than demand at the intervention price, market forces would normally cause prices to fall. Intervention buying removes the surplus from the market;

(2) import levies (tariffs) to ensure that imports cannot enter the EU more cheaply from non-member countries;

(3) export subsidies, which bridge the gap between the high internal price and the lower world price, enabling the disposal of intervention stocks. 
Table 1. Common Agricultural Policy mechanisms and their impact

(From Cawley et al. 1994)

\begin{tabular}{|c|c|c|}
\hline Sector & Mechanism & Impact \\
\hline Dairy & $\begin{array}{l}\text { Intervention buying, export refunds, and } \\
\text { import levies } \\
\text { Quotas on production } \\
\text { Subsidized internal disposals }\end{array}$ & $\begin{array}{l}\text { Higher milk and milk-product prices to } \\
\text { producers and consumers } \\
\text { Limit surpluses } \\
\text { Lower prices to those affected }\end{array}$ \\
\hline Beef & $\begin{array}{l}\text { Suckler cow premium } \\
\text { Beef special premium } \\
\text { Intervention buying, export refunds, and } \\
\text { import levies } \\
\text { Subsidized internal disposals }\end{array}$ & $\begin{array}{l}\text { Raise beef production } \\
\text { Raise beef production } \\
\text { Higher prices to consumers and producers } \\
\text { Raise beef consumption of those affected }\end{array}$ \\
\hline Sheep & $\begin{array}{l}\text { Ewe premium } \\
\text { Import arrangements }\end{array}$ & $\begin{array}{l}\text { Higher lamb production and lower prices } \\
\text { Limit imports, maintain higher prices }\end{array}$ \\
\hline $\begin{array}{l}\text { Pigs, eggs } \\
\text { and poultry }\end{array}$ & Export refunds and import levies & Offset higher cereal feed prices \\
\hline Cereals & $\begin{array}{l}\text { Intevention buying, export refunds, and } \\
\text { import levies } \\
\text { Area payments } \\
\text { Set-aside }\end{array}$ & $\begin{array}{l}\text { Higher prices to producers and consumers } \\
\text { Neutral impact for consumers } \\
\text { Reduce surpluses }\end{array}$ \\
\hline Oilseeds & $\begin{array}{l}\text { Intervention, minimum prices } \\
\text { Area payments } \\
\text { Set-aside }\end{array}$ & $\begin{array}{l}\text { Higher prices to producers } \\
\text { Neutral impact for consumers } \\
\text { Reduce surpluses }\end{array}$ \\
\hline Olive oil & $\begin{array}{l}\text { Intervention buying, export refunds, } \\
\text { import levies } \\
\text { Producers and packer subsidies }\end{array}$ & $\begin{array}{l}\text { Higher prices to producers and consumers } \\
\text { Higher production, lower prices }\end{array}$ \\
\hline Sugar & $\begin{array}{l}\text { Intervention, export refunds, import levies } \\
\text { Production quotas }\end{array}$ & $\begin{array}{l}\text { Higher prices to producers and consumers } \\
\text { Limit production }\end{array}$ \\
\hline $\begin{array}{l}\text { Fruit and } \\
\text { vegetables }\end{array}$ & $\begin{array}{l}\text { Intervention, export refunds, minimum } \\
\text { import prices } \\
\text { Quality requirements }\end{array}$ & $\begin{array}{l}\text { Higher prices to producers and consumers } \\
\text { Lower supplies, higher prices, higher quality }\end{array}$ \\
\hline Fish & $\begin{array}{l}\text { Quotas } \\
\text { Minimum prices }\end{array}$ & $\begin{array}{l}\text { Lower supplies, higher prices } \\
\text { Higher prices }\end{array}$ \\
\hline
\end{tabular}

Of course, the CAP contains other mechanisms for specific products, some of which influence the level of consumption of particular groups of consumers (for example, subsidized sales of butter to low-income consumers and non-profit-making institutions). Others are intended to reduce the budgetary effects of the CAP, such as milk quotas and cereal setasides and have no clear or direct impact on consumption. Table 1, which is derived from Cawley et al. (1994), shows the main CAP mechanisms for individual products as they stand at the current time. These mechanisms are subject to change as a result of the ongoing reform of agricultural policy in the EU and GATT. For example, a new regime for the support of fruit and vegetable producers is currently being introduced.

\section{Impact on consumption}

We have seen that price elasticities tend to be low for food products; therefore, actions that 
Table 2. Implied consumption effects of the Common Agricultural Policy (CAP) in the UK, 1988-92 (From Cawley et al. 1994)

\begin{tabular}{|c|c|c|c|c|c|}
\hline Product & $\begin{array}{l}\text { Average retail } \\
\text { price } \\
\text { (pence/lb)* }\end{array}$ & $\begin{array}{c}\text { Effect of CAP } \\
\text { on producer } \\
\text { price } \dagger \\
\text { (pence/lb) }\end{array}$ & $\begin{array}{l}\text { Implied } \\
\text { impact on } \\
\text { consumer } \\
\text { price } \ddagger(\%)\end{array}$ & $\begin{array}{c}\text { Price } \\
\text { elasticity§ }\end{array}$ & $\begin{array}{c}\text { Implied } \\
\text { impact on } \\
\text { consumption } \\
(\%)\end{array}$ \\
\hline Milk & $29 \cdot 3$ & 6.9 & $23 \cdot 5$ & -0.29 & $-6 \cdot 8$ \\
\hline Cheese & 156.7 & 51.6 & 32.9 & -1.20 & $-39 \cdot 5$ \\
\hline Beef & $195 \cdot 8$ & 67.6 & $34 \cdot 6$ & -1.25 & $-43 \cdot 2$ \\
\hline Pork & 147.8 & $12 \cdot 1$ & 8.2 & -1.73 & $-14 \cdot 2$ \\
\hline Poultry & $105 \cdot 4$ & 8.8 & 8.4 & -0.13 & $-1 \cdot 1$ \\
\hline Eggs & 103.7 & 11.6 & 11.2 & $\mathrm{n} / \mathbf{a}$ & n/a \\
\hline Butter & 106.9 & $61 \cdot 5$ & 57.5 & -0.55 & $-31 \cdot 6$ \\
\hline Sugar & $29 \cdot 1$ & 1.8 & $6 \cdot 3$ & -0.24 & $-1 \cdot 5$ \\
\hline Bread & $27 \cdot 1$ & 1.9 & $7 \cdot 1$ & -0.09 & -0.6 \\
\hline
\end{tabular}

n/a, Not available.

* Except milk (pints) and eggs (dozens).

$\dagger$ Based on Organization for Economic Cooperation and Development (1994) estimates.

¥ Assuming perfect price transmission and no impact on world prices.

$\S$ National Food Survey estimates (based on values published annually by the Ministry of Agriculture, Fisheries and Food in the Annual Report of the National Food Survey Committee).

affect overall price levels are unlikely to have a major impact on consumption of food products in developed countries. In analysing the actual impact, a first step is to derive the price implications for consumers of the CAP for different commodity groups, and apply estimated price elasticities of demand to these.

In carrying out such an analysis, some simplifying assumptions must be made. First, in estimating the price implications of the CAP, it is common practice to compare prices to consumers at the retail level with prices that would have existed in the absence of the CAP. Since the EU is not a small country in the way defined previously, and consequently its internal actions do influence world prices, the procedure for analysing the price impact of the CAP (by comparing its internal prices with those on world markets) is an approximation. By raising prices to farmers, the CAP has stimulated production of food which has had to be disposed of on world markets, which in turn has depressed world prices. Thus, the ratio, internal prices:world prices is an overstatement of the price effect of the CAP. It is nevertheless a useful approximation, which avoids the necessity of complex international commodity price modelling.

Second, the policy instruments of the CAP are applied at or close to the farm gate, whereas consumers are presented with prices at the retail level. It is normal to assume that prices are perfectly transmitted from farm to retail level. In other words, an increase in the price of wheat, for example, has a direct influence on the price of bread equal to the increased cost of the wheat in a loaf of bread. However, in practice things are a little more complicated, which suggests that the impact of changes in farm-gate prices on retail prices may be less important than in the past. First, as consumption trends increasingly favour 'value-added' products, the value of the raw material relative to the price of the finished product is in decline. It is currently about one-third, averaged over all food products, but considerably less for many convenience foods. Manufacturers might not consider it worth- 
Table 3. European sales of butter at reduced prices by type of measure, 1993 (From Residuary Milk Marketing Board, 1995)

\begin{tabular}{lccc}
\hline \hline & \multicolumn{3}{c}{ Total sales $\left(\times 10^{3}\right.$ tonnes $)$} \\
\cline { 2 - 4 } Type of measure & $\begin{array}{c}\text { Intervention } \\
\text { stocks }\end{array}$ & $\begin{array}{c}\text { Market } \\
\text { butter }\end{array}$ & Total \\
\hline Incorporation into bakery products & 23.2 & 293.7 & 316.9 \\
Incorporation into ice-cream & $5 \cdot 3$ & $69 \cdot 3$ & 74.7 \\
Sales to non-profit-making organizations & - & 37.6 & 37.6 \\
Processing into concentrated butter & 0.2 & 21.5 & $21 \cdot 7$ \\
Subsidized consumption & - & - & - \\
Distribution to deprived persons & 7.8 & - & $7 \cdot 8$ \\
Sales to persons on social assistance & - & $7 \cdot 4$ & $7 \cdot 4$ \\
Total & 36.8 & 429.5 & 466.3 \\
\hline
\end{tabular}

while to pass on small cost changes (and consumers may not, in any case, react to small proportional price changes). Second, the pricing strategies of major food manufacturers and retailers may mitigate against fully passing on even large proportional changes in raw material prices (Colman, 1985; Traill \& Henson, 1994). However, some empirical evidence suggests that price changes of raw materials are fully passed through in the long term (Palaskas, 1995).

Table 2, derived from Cawley et al. (1994), has been calculated using these two simplifying assumptions. It implies that the consumption effects of the CAP have been substantial for some products, notably cheese, butter and beef, but insignificant in the case of poultry, bread and sugar. The impact of the CAP on fruit and vegetable consumption has not been considered in Table 2 since the support regime in this case is specific to each individual product; generally fruit and vegetable prices have been affected less than other prices.

Even given the simplifying assumptions made, these changes are a considerable overestimate of the impact of the CAP. Remember that the definition of price elasticity refers to the change in consumption due to a unit percentage change in price, assuming that all other prices are held constant. This assumption has been violated by changing all prices simultaneously. Thus, while Table 2 implies that the CAP has reduced consumption of all food products (although some more than others), in fact, the overall consumption of food (whether measured as energy content or physical quantity) is almost totally insensitive to the overall price of food. What happens is that consumers switch between food products in their overall diets in response to changes in the relative prices of individual food items.

Far more important than the overall level of food prices are the relative prices of alternative food products, particularly of close substitutes. Thus, a subsidy that lowers the price of, for example, poultry relative to beef (as is seen to have happened) gives a significant boost to poultry consumption and a reduction in that of beef. The other main product group that has seen a substantial increase in prices is dairy products, but with the exception of butter, there are no close substitutes.

The increased effectiveness of a price policy, when used to influence the relative price of close substitutes, suggests that action could be undertaken to lower the price of poly- or monounsaturated fats relative to butter, or of semi-skimmed milk relative to full-fat milk. However, measures aimed at affecting consumption across groups that are not close sub- 


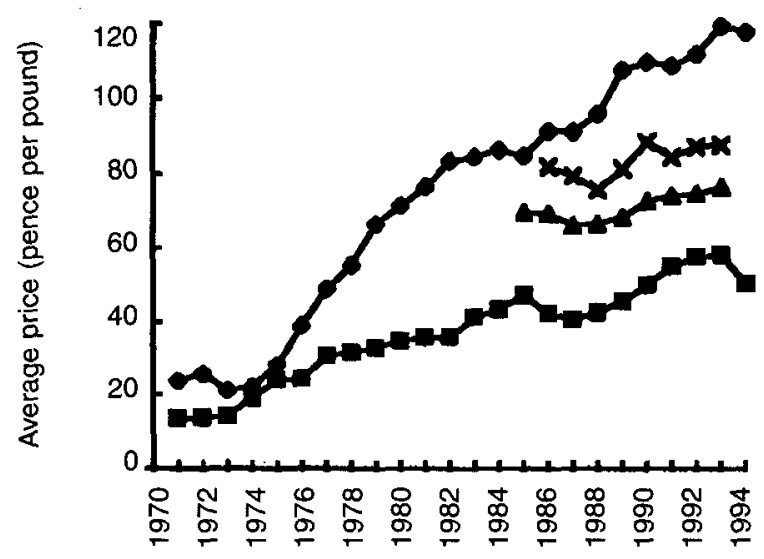

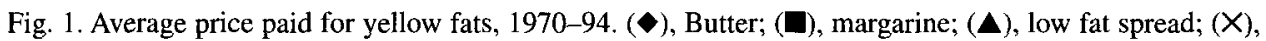
reduced-fat spread. (From Henson, 1992; Henson et al. 1994)

stitutes, for example to encourage consumption of fruit and vegetables, are likely to be ineffective.

The European Commission has sought to offset the downwards pressure on the consumption of products supported under the CAP through a variety of mechanisms. These have included the provisions of funds for product promotion, for example beef and butter, or subsidies to partially offset the impact of the CAP on market prices, for example butter. To minimize displacement of full-price sales, subsidies are generally restricted to certain markets, for example sales to the food industry or to particular groups of consumers.

The conclusion that the CAP has had little impact on consumption should be accompanied by a few words of warning. It is probable that particular groups, notably those on low incomes, who are more sensitive to price changes, have been affected. Thus, their consumption of those products in Table 2 which have seen large price rises under the CAP will have been most affected. The CAP also influences food consumption of lower-income groups in another important way. The proportion of income spent on food by the poor may be substantial, and the overall burden of paying for the CAP through higher food prices is equivalent to a reduction in overall purchasing power. Consumers react to this by purchasing fewer high-value products and more low-value products (Tomek \& Robinson, 1972). Whether this is nutritionally harmful is debatable (low-value products probably include unprocessed fruit and vegetables; high-value products are likely to include meat and dairy products and highly-processed foods).

\section{The case of yellow fats}

To provide a more comprehensive view of the mechanisms through which the CAP might influence consumption of particular food products, we now consider the case of yellow fats, (for further details, see Henson, 1992; Henson et al. 1994). This is a particularly interesting example, since the CAP supports the price of the raw material in both butter and margarine, but in quite different ways, with important implications for relative prices.

In the case of butter, the price paid to dairy farmers is supported via increases in the price of the storable components of milk, i.e. butter and skimmed-milk powder (SMP). This is 


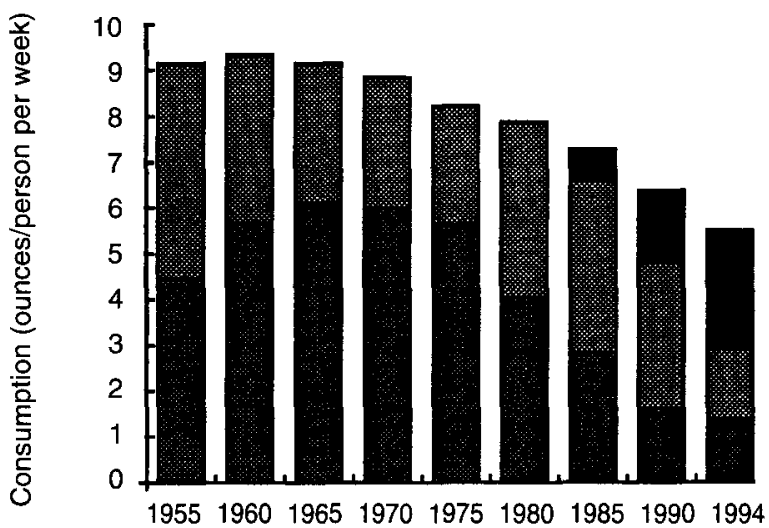

Fig. 2. Household consumption of yellow fats, 1955-94. ( $\mathrm{C}$ ), Reduced or low-fat spread; ( ), margarine; ( $)$, butter. (From Henson, 1992; Henson et al. 1994).

achieved through a variable levy on imports of butter and SMP, and domestic price support through intervention buying. This regime has been highly effective at stimulating production, and by the early 1980 s had resulted in the infamous 'mountains' of butter and SMP. Consequently, milk production has been effectively capped since 1984 through the imposition of milk quotas.

In the case of oilseeds, the major raw material for margarine production, farmers are essentially supported through an annual area payment which is 'decoupled' from total production. Consequently, in most years the CAP has little direct effect on the price of oilseed and, thus, the price of margarine. (Recent work by Traill \& Henson (1994) indicates that, because of the level of concentration in the manufacture of yellow fats and the close substitutability between butter and margarine, the price of margarine shadows the price of butter. As a consequence, the CAP has resulted in an increase, albeit limited, in the price of margarine.)

Noting the complications inherent in this analysis referred to previously in particular the degree to which changes in agricultural support prices are passed on to consumers, the CAP has undoubtedly resulted in a significant widening of the gap between butter and margarine prices. This is well illustrated by the trend in these prices in the UK since 1970 (Fig. 1). Remember that the UK joined the EU in the early 1970s and progressively adopted the mechanisms of the CAP over the period to 1979. The widening of the gap between butter and margarine prices over this period (and beyond) is clearly discernible.

Over the same period, the consumption of butter relative to margarine has declined significantly (Fig. 2). The obvious question is whether this is due to the increased price of butter relative to margarine, or other factors. Whilst acknowledging the importance of concerns about saturated fat intake and the introduction of dairy spreads as key factors in the demand for butter, empirical modelling of the yellow-fats market supports the argument that the CAP has exerted a significant downwards pressure on the demand for butter in the UK.

The European Commission acknowledges the decline in butter consumption as a result of the CAP and sought to offset this impact through a number of schemes which offer butter for sale at reduced prices (Table 3). These schemes include butter for incorporation into 
ice cream and bakery products, sales to non-profit-making organizations and persons on social assistance, and free distribution to deprived persons. In addition, a general subsidy on butter consumption has been applied in some years.

In practice, reduced-price butter schemes are relatively ineffective at stimulating the demand for butter, tending to displace full-price sales rather than generating new sales. In aggregate it is estimated that each kilogram of reduced-price sales increases the demand for butter by $0.31 \mathrm{~kg}$, but at the same time displaces $0.69 \mathrm{~kg}$ of full-priced sales (Henson et al. 1994). As a result, reduced-price sales have proved to be an extremely expensive mechanism for attempting to reduce butter surpluses.

\section{THE NEW COMMON AGRICULTURAL POLICY: MaCSHARRY AND GENERAL AGREEMENT ON TARIFFS AND TRADE}

It would be remiss not to mention the reforms of the CAP resulting from the changes introduced by Commissioner MacSharry and, more importantly, the pressures of GATT. However, we will do little more than mention them because their impact on consumption will probably not be substantial. The main effect is to shift the burden of support from consumers towards taxpayers through payments by governments to farmers. The reduction of the burden on consumers comes through a reduction in prices, and a commitment to reduce tariffs by an average of $20 \%$ per tariff line over the implementation period. Probably, the pressure for change will continue in future GATT agreements, and as a consequence of enlargement of the EU. In the long term, therefore, we must expect to see a reversal of the effects that have already been noted. Those products that have received the highest rates of protection will experience the sharpest reductions in prices. However, prices to consumers will not fall by the full $36 \%$, since measures to reduce production world-wide will lessen the burden of surpluses such that world price rises will partially offset the fall.

\section{CONCLUSIONS}

Popular opinion has often taken the view that the main purpose of the CAP has been to subsidize farmers and that this has resulted in increased production and consumption of those products most heavily subsidized. Also, that these products may be nutritionally harmful, in particular beef and dairy products (the existence of large intervention stocks has been cited as evidence). Less-heavily-subsidized products, notably fruit and vegetables, which are 'good for you' have been perceived to be discouraged. We have argued in the present paper that, in fact, consumers have been taxed as a result of the CAP. The impact on food consumption has probably not been very great, but to the extent that consumption has been affected, it is beef and dairy products that have suffered, and white meat and fruit and vegetables that have benefited. Economist colleagues have been heard to mutter that the CAP is the most effective nutrition intervention policy ever invented.

\section{REFERENCES}

Cawley, D., Lee, A. \& Lund, P. (1994). The Common Agricultural Policy and the UK Diet. Paper presented to the 36th Seminar of the European Association of Agricultural Economics, Reading, 19-21 September 1994.

Colman, D. (1985). Imperfect transmission of policy prices. European Review of Agricultural Economics 12, 171-186. 
Department of Health and Social Security (1984). Diet and Cardiovascular Disease. Report of the Committee on Medical Aspects of Food Policy. London: H.M. Stationery Office.

Henson, S. J. (1992). The CAP and healthy eating: the case of butter. Paper presented at the conference on The CAP and Healthy Eating, The University of Reading, December 1992.

Henson, S. J. (1995). Demand-side constraints on the introduction of new food technologies: the case of food irradiation. Food Policy 20, 111-128.

Henson, S. J., Loader, R. J. \& Traill, W .B. (1995). Contemporary food policy issues and the food supply chain. European Review of Agricultural Economics 22, 271-281.

Henson, S. J., Traill, W. B. \& Rayner, M. (1994). The Common Agricultural Policy and Health: the Implications for Health. London: Coronary Prevention Group.

Organization for Economic Cooperation and Development (1981). Food Policy. Paris: Organization for Economic Cooperation and Development.

Organization for Economic Cooperation and Development (1994). Agricultural Policies, Markets and Trade in OECD Countries: Monitoring and Outlook 1994. Paris: Organization for Economic Cooperation and Development.

Palaskas, T. B. (1995). Statistical analysis of price transmission in the EU. Journal of Agricultural Economics 46, 61-69.

Residuary Milk Marketing Board (1995). Dairy Facts and Figures. Thames Ditton: Residuary Milk Marketing Board.

Ritson, C. (1983). Food and nutrition policy: the ultimate goal. In The Food Industry: Economics and Policies, pp. 167-176 [J. A. Burns, J. McInerney and A. Swinbank, editors]. London: Heinemann.

Tomek, W. G. \& Robinson, K L. (1972). Agricultural Product Prices. Ithaca: Cornell University Press.

Traill, W. B. \& Henson, S. J. (1994). Price transmission in the United Kingdom yellow fats market in the presence of imperfect competition. Journal of Agricultural Economics 45, 123-131. 